\title{
Crayfish process leaf litter in tropical streams even when shredding insects are common
}

\author{
Jacqui F. Coughlan ${ }^{A}$, Richard G. Pearson ${ }^{A}$ and Luz Boyero ${ }^{A, B}, C$ \\ A School of Marine and Tropical Biology, James Cook University, Townsville, Qld 4811, Australia. \\ BWetland Ecology Group, Doñana Biological Station-CSIC, Isla Cartuja, Sevilla 41092, Spain. \\ ${ }^{\mathrm{C}}$ Corresponding author. Email: luz.boyero@ebd.csic.es
}

\begin{abstract}
Comparisons of leaf-litter processing in streams suggest that tropical streams have fewer leaf shredders than temperate streams and that insect shredders might be replaced by other taxa such as Crustacea in tropical systems. Australian wet-tropical streams have abundant insect shredders, and also abundant crayfish, which may contribute to litter processing. We monitored litter input and retention in a Queensland rainforest stream to determine availability of litter in different seasons, and we conducted experiments to test the hypothesis that crayfish were important contributors to litter processing. Litter fall peaked in the late dry season and litter accumulated steadily in pools, whereas in riffles, the standing crop was maintained at a threshold level. All accumulated litter was washed from the stream during a flood. The crayfish, Cherax cairnsensis, readily fed on leaves. Its processing rate was related negatively to leaf toughness and positively to leaf nitrogen content. The crayfish assimilated up to $28.5 \%$ of the material processed at $248 \mathrm{C}$, and none at $118 \mathrm{C}$. These results confirm that there are alternatives to insect shredders in tropical streams, even when insect shredders are abundant.
\end{abstract}

Additional keywords: allochthonous material, Cherax, decomposition, litter processing, rainforest stream, shredder.

\section{Introduction}

Forested headwater stream communities in temperate areas depend on allochthonous detritus inputs from the adjacent terrestrial vegetation (Benfield and Webster 1985; Cummins et al. 1989). However, there is some controversy regarding the relative importance of allochthonous v. authochthonous energy sources in tropical headwater streams (Cheshire et al. 2005; Lau et al. 2009). Whereas some tropical streams have a numerically and functionally important insect shredder guild similar to that of temperate streams (e.g. in peninsular Malaysia; Yule et al. 2009), others are fuelled by primary production, with little contribution of litter to shredding (e.g. in Hong Kong; Lau et al. 2008).

In some cases, stream insect shredders are scarce and they are functionally replaced by other taxa - e.g. snails, semi-terrestrial cockroaches, crabs or crayfish (Dobson 2004; Yule et al. 2009). Crayfish are often a conspicuous component of tropical stream communities, yet little has been reported about their contribution to litter breakdown in tropical streams (but see Rosemond et al. 1998). However, they are known to greatly promote litter breakdown in some temperate streams (Usio 2000) and detritus is reported to be their primary food source in many aquatic ecosystems, including streams (Lorman and Magnuson 1978; Growns and Richardson 1988). Recent literature suggests that litter breakdown rates are affected by shredder and litter species diversity, and by the identity of the species involved (Jonsson and Malmqvist 2003a; Bastian et al. 2008). The role of insect shredders in Australian tropical streams is well known (Nolen and Pearson 1993; Bastian et al. 2007), but not that of the crayfish Cherax cairnsensis Riek (Parastacidae), which is a prominent member of the fauna (Boyero et al. 2006).

The aim of the present study was to determine whether crayfish were an alternative litter processor to insects in a tropical stream and, therefore, whether they were an alternative source of fine particulate matter in the detritus-dominated food web (Cheshire et al. 2005). We hypothesised that (1) suitable litter is available across seasons, potentially allowing yearround contributions to the food web, (2) crayfish have no role in litter processing and (3) if a role were to be demonstrated, it would not be influenced by temperature, leaf identity and/or leaf quality (level of conditioning and toughness).

\section{Materials and methods}

Study site

The site for the field study was a 400-m reach of Birthday Creek $\left(19800^{\circ} \mathrm{S}, 146811^{\circ} \mathrm{E}\right)$, commencing , $200 \mathrm{~m}$ from the stream source. The site is at an elevation of $860 \mathrm{~m}$ asl and , $80 \mathrm{~km}$ north of Townsville, north-eastern Queensland. The climate is tropical and seasonal, with most rain usually falling between December and March. Tropical storms (cyclones) occur unpredictably during the wet season (not every year) and cause severe floods. During the present study, water temperatures ranged from 11.08C (July) to 21.58C (February). Stream width was 2.5-4.0 m and the rainforest canopy was unbroken at the site (further details are given in Nolen and Pearson 1992). 


\section{Litter fall and standing crop}

To test the hypothesis that litter was available across seasons, litter fall was collected monthly from 15 vertical litter traps placed in the riparian vegetation (see Benson and Pearson 1993). Lateral litter input and blow-in were minimal at this site (Benson and Pearson 1993). The standing crop of coarse litter (CPOM 4 $1 \mathrm{~mm}$ ) on the streambed was measured monthly in 10 random $0.25-\mathrm{m}^{2}$ quadrats (five in pools and five in riffles). Litter was wet-weighed in the field to $0.1 \mathrm{~g}$ with a Pesola spring balance (Pesola AG, Baar, Switzerland) and returned to the stream. Wood and leaf material were separated before weighing; however, only data on the leaf fraction are presented here. Litter dry weight was estimated from an unweighted least-squares linear regression of litter wet weight v. oven-dry weight of 1 month's samples. Raw data were used in the regression because the residuals were normally distributed.

\section{Litter-processing experiments}

To test the hypothesis that leaf identity did not affect processing rates by crayfish, leaves from four species of rainforest trees from the riparian zone of Birthday Creek were used in leafbreakdown experiments. Leaves were chosen partly on the basis of their predominance in stream leaf packs (R. W. Davies, University of Calgary, pers. comm.) and partly to coincide with other studies of leaf processing in Birthday Creek (Nolen and Pearson 1993). The leaf species were from the tree species Apodytes brachystylis Mueller (Icacinaceae), Cryptocarya densiflora Blume (Lauraceae) and Cryptocarya leucophylla Hyland (Lauraceae) and the fern Marattia salicina Smith (Marattiaceae).

Preliminary observations of 12 crayfish in the laboratory over a 1-month period established that they did not eat fresh leaves, so we tested the hypothesis that leaf condition did not affect processing by crayfish on dried leaves. Senescent leaves were not used, because sufficient numbers of leaves of known origin and age could not be collected. Leaves were picked from an individual tree of each species to minimise the effect of among-species variation; however, subsequent trials demonstrated that leaves from different trees did not differ in their nitrogen content (see below). The leaves were placed in artificial stream channels with water supplied from Birthday Creek (as in Pearson and Connolly 2000) to allow conditioning for 2, 4 and 10 weeks. Mesh partitions $(63 \mathrm{~mm})$ in the channels excluded macro-processors, while allowing microbial colonisation, and a mesh screen over the top of the channels prevented access by ovipositing insects.

For each experiment, leaves were wet-weighed into bundles of , $3 \mathrm{~g}$ (measured to the nearest $0.01 \mathrm{~g}$ ). Initial oven-dry weight of the litter was estimated using unweighted leastsquares linear regressions of leaf wet weight v. oven-dry weight. Regression analyses were repeated for each species at each conditioning time. Raw data were used in the regressions because the residuals were normally distributed. Controls in each experiment contained leaves but no crayfish, which allowed estimation of weight change owing to leaching and microbial processing and/or growth. Control tanks were randomly interspersed with treatment tanks. Experimental animals were collected from the study site at Birthday Creek and maintained in aerated glass tanks $(23 \mathrm{~cm} \times 15 \mathrm{~cm} \times 15 \mathrm{~cm})$.
Between Experiments 1 and 2, they were fed on mixed conditioned leaves from Birthday Creek.

Experiments were monitored daily and qualitative observations were recorded along with maximum/minimum water temperatures for each 24-h period. After each experiment, the remaining leaf material was oven-dried at $658 \mathrm{C}$ for at least $24 \mathrm{~h}$ and weighed to the nearest $0.01 \mathrm{~g}$. The amount of leaf material processed was then determined. Treatment values were adjusted for control effects before determining the amount of material processed. All results are expressed as the amount of leaf material processed per gram of crayfish bodyweight.

\section{Experiment 1: processing of leaves of different species and degrees of conditioning by $\mathrm{C}$. cairnsensis}

This experiment was conducted to test the hypothesis that leaf species and condition (immersion period) have no effect on the quantity of leaf processed. All combinations of leaf species and condition (2, 4 and 10 weeks' immersion) were used. The experiment was conducted in three consecutive 11-day phases, one per conditioning time. Each treatment contained a 3$\mathrm{g}$ bundle of each leaf species (12 $\mathrm{g}$ total) and one crayfish. This allowed crayfish to choose between four species, all of which had been subjected to the same conditioning period. Ten replicates and five controls were used. For the purposes of analysis, it was assumed that the trends observed were due to effects of species and condition and that time had no effect, because the temperature remained constant (T2.08C) for the duration of the experiment and the same animals were used each time.

Data were analysed with a split-plot ANOVA (Snedecor and Cochran 1980), with leaf condition (i.e. conditioning period fixed factor) as the main plot and crayfish mass (random factor) as the subplot. Leaf species identity was a fixed factor. The choice of leaf species to be used in subsequent experiments was based on the results of this experiment. Raw data were used as the assumptions of the ANOVA were met.

We performed a further trial to validate the results of Experiment 1, because the preference for leaves of all conditions was not determined concurrently. Leaves of A. brachystylis (the most preferred species in Experiment 1) were conditioned by placing them in the artificial streams at different times and removing them at the same time so that the crayfish could choose among all conditions of this species. Twelve replicates and six controls were used. Leaves were labelled with Dymo tags (http:// global.dymo.com/enAU/Home/default.html). The 12 treatment tanks comprised six with animals from the previous experiment and six with animals collected from the stream immediately before running the experiment. This allowed us to determine whether the prior acclimation of the animals to laboratory conditions had any effect on their performance in previous experiments. The experiment was conducted at 248C over 4 days. Data were analysed with a two-way ANOVA; again, the untransformed data met the assumptions of the analysis.

\section{Experiment 2: effect of temperature on processing rate, production of fine particulate organic matter and assimilation efficiency of $C$. cairnsensis}

This experiment was conducted to test the hypothesis that temperature has no effect on litter processing and assimilation 
by crayfish. Trials were run at $118 \mathrm{C}$ and $248 \mathrm{C}$, temperatures reflecting the minimum and maximum typically measured in Birthday Creek. A. brachystylis, conditioned for 10 weeks, was used because this leaf species showed maximum processing rates in Experiment 1. Approximately $3.0 \mathrm{~g}$ of leaf material was wet-weighed, and then placed in each tank with one crayfish. Control tanks included leaf material but no crayfish.

Crayfish in the $118 \mathrm{C}$ treatment were acclimated by lowering the temperature by 38C every 3 days. During this period, animals were not fed so that any fine organic matter collected at the end of the experiment resulted from processing of the experimental leaves. At the beginning of each experiment, all tanks were cleaned thoroughly and filtered fresh water was added to the tanks.

Five replicates and three controls were used in each treatment. The experiment was terminated after 6 days because animals at 248C had processed most of the leaf material. Remaining intact leaf material was removed and the water was sieved through 1-mm and 63-mm screens to separate fragmentary coarse particulate organic matter (CPOM) and fine particulate organic matter (FPOM), which were then vacuumfiltered on to pre-weighed Whatman qualitative (No. 1) filter papers. All material was then oven-dried at $658 \mathrm{C}$ for $24 \mathrm{~h}$ and weighed to the nearest $0.01 \mathrm{~g}$. The amount of leaf processed and CPOM and FPOM produced were then determined. Adopting the terminology from Bird and Kaushik (1985), assimilation was defined as follows:

\section{Mean assimilation efficiency ð\%р \\ $1 / 4$ ðmass processed - fragmentary mass remaining $p=$ \\ mass processed $\times 100$}

where mass processed is the amount of leaf material that has been processed and fragmentary mass remaining is the sum of faecal material, FPOM and fragmentary CPOM. Assimilation estimates may be exaggerated because of the possibility of losses owing to microbial respiration and dissolution of organic material, especially at the higher temperature. Data were analysed with one-way ANOVA; data met the assumptions of the analysis.

\section{Leaf properties}

Toughness of each leaf species at each conditioning time was determined with a penetrometer (Graça and Zimmer 2005) and the results were expressed as the mass required to penetrate $1 \mathrm{~mm}^{2}$ of leaf surface. Two measurements were taken from each of four individual leaves of each species-condition combination. Data were analysed with a two-way ANOVA, with level of conditioning and leaf species as the two fixed factors; data met the assumptions of the analysis.

Nitrogen content of each leaf species at each conditioning time was determined by micro-Kjeldahl digestion (Bremmen and Mulvaney 1982). Composite samples of several leaves were dried at $858 \mathrm{C}$ for $24 \mathrm{~h}$ and ground in a Thomas-Wiley No. 4 laboratory mill (http://www.gmi-inc.com/Thomas-Wiley-Laboratory-MillModel-4.html) with a 1-mm screen. Weighed samples of $200 \mathrm{mg}$ were digested in $3 \mathrm{~mL}$ of concentrated sulfuric acid with a selenium catalyst. The digest was made up to $100 \mathrm{~mL}$ and nitrogen content was determined with an auto-analyser.
Nitrogen content was similarly determined for (1) fresh green leaves from five trees of each species to give an indication of the amount of within-species variation and (2) senescent leaves of known age that were collected from sheets placed on the forest floor. Senescent M. salicina leaves were not found during this period, so were not available for analysis of nitrogen content.

\section{Results}

\section{Litter fall and standing crop}

Total litter fall over 8 months comprised (by weight) 75\% leaf, $13.5 \%$ small wood, $8.6 \%$ reproductive material and $2 \%$ miscellaneous plant debris. The peak in total litter fall occurred in the late dry season (October-November) and consisted of $94.2 \%$ leaf material (Fig. 1a). A secondary peak in the total litter fall in March was caused by the increased fall of wood resulting from Cyclone Ivor. At this time, wood constituted $39.4 \%$ of the total litter fall and leaves constituted $45.6 \%$. Following Cyclone Ivor, a predominance of fresh green litter was noted in leaf fall and much new growth was observed in the riparian vegetation.

The equation to describe the relationship between wet and oven-dry weight of CPOM was as follows,:

$$
\begin{aligned}
& \text { Dry weight } 1 / 4 \text { ð0:2032 } \times \text { wet weightp }-1: 7865 \\
& \text { ðn } 1 / 430, r^{2} 1 / 4 \text { 0:9987, P O 0:001p: }
\end{aligned}
$$

The monthly standing crop of CPOM was similar in riffles and pools until late summer, when an increase in the pools was

(a)
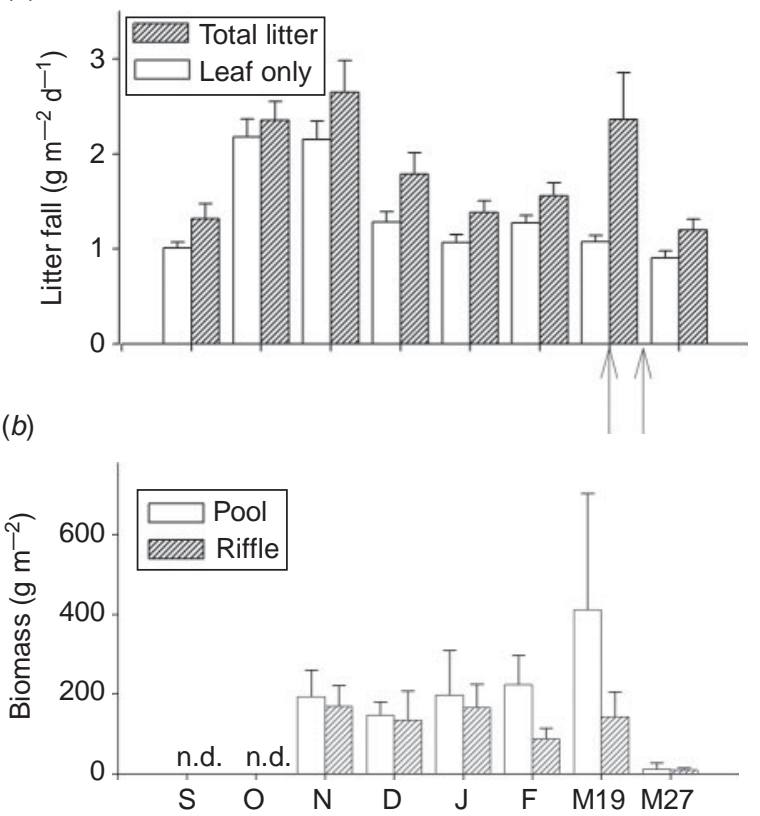

Fig. 1. (a) Pattern of litter fall (leaf only and total litter, ps.e.) from the riparian vegetation of Birthday Creek; $\mathrm{n} 1 / 415$ litter traps. (b) Biomass of litter in pools and riffles on the stream bed; $\mathrm{n}^{1 / 4} 10 \times 0.25 \mathrm{~m}^{2}$ quadrats. The $\mathrm{x}$-axis indicates the months September to March, with two dates in March (19 and 27). The arrows indicate the timing first of strong winds and second of flooding resulting from Cyclone Ivor; n.d. $1 / 4 / 4$ no data. 
apparent, reaching a peak of $412 \mathrm{~g} \mathrm{~m}^{-2}$ in March (Fig. 1b). Heavy rains in late March, following Cyclone Ivor, caused flooding, which washed the accumulated litter from the stream.

\section{Litter-processing experiments}

All leaf types showed significant linear relationships between leaf wet weight and oven-dry weight (Table 1). The amount of variation explained by the equation $\left(\mathrm{r}^{2}\right)$ ranged from $52 \%$ to 97\%. The relationships were very similar for the two Cryptocarya species and similar for M. salicina and A. brachystylis, and suggested that the Cryptocarya species hold less water than do the other species. C. cairnsensis shredded leaf material in the following two ways: usually it held the leaf upright between its chelae and used its maxillipeds to tear small pieces from the leaf edge and transfer them to its mouth; alternatively, it held the leaf flat on the substratum with its chelae and used the chelate pereiopods to tear small pieces from the leaf edge and transfer them to the mouth. Both modes of feeding were observed in the laboratory and in the stream. The maximum variation in water temperatures in the experimental tanks over any 24 -h period was $2.08 \mathrm{C}$.

\section{Experiment 1: processing of leaves of different species and degrees of conditioning}

There were significant differences in the amount of leaf processed by $\mathrm{C}$. cairnsensis among leaf species $\left(\mathrm{F}_{3,9} 1 / 421.14, \mathrm{P} \mathbf{O}\right.$ $0.0001)$ and among leaf conditions $\left(F_{2,9} 1 / 410.47, \mathrm{P}^{1 / 4} 0.0010\right)$ (Fig. 2). There was a consistent preference for leaves of A. brachystylis and, for those species that were consumed (A. brachystylis and M. salicina), there was a preference for maximally conditioned leaves. A pairwise comparison of means by the least significant difference method showed processing of A. brachystylis to be significantly higher than that of M. salicina. Both species were processed in significantly greater amounts than Cryptocarya leucophylla or C. densiflora. There was no significant difference between the amounts processed of the Cryptocarya species $\left(\mathrm{t}_{1,27} 1 / 42.052, \mathrm{P} 40.05\right)$. The negative processing values for $\mathrm{C}$. leucophylla and $\mathrm{C}$. densiflora probably resulted from leaf weight gain owing to microbial growth, as typically occurs during leaf processing (e.g. Pearson and Tobin 1989).

Leaves conditioned for 2 and 4 weeks were not processed in significantly different amounts from each other; however, they were processed significantly less than leaves conditioned for 10 weeks $\left(\mathrm{t}_{1,18} \frac{1 / 4}{4} 2.101\right.$, P O 0.05). A significant interaction between the leaf condition and species $\left(\mathrm{F}_{2,6} 1 / 411.53\right.$, P O 0.0001 ) reflects the absence of processing at any condition for



Fig. 2. Amount of leaf processed by crayfish $(100 \times \mathrm{g}$ dry leaf matter consumed per day per gram crayfish body mass $1 / 4 \% T$ s.e.) for each leaf species at each condition (2, 4 and 10 weeks' conditioning period); $\mathrm{n} 1 / 410$ for treatment, and $n 1 / 45$ for control. A.b. $1 / 4$ Apodytes brachystylis, M.s. 1/4 Marattia salicina, C.d. $1 / 4$ Cryptocarya densiflora, C.l. $1 / 4$ Cryptocarya leucophylla.

Table 1. Results of regression analyses of leaf wet weight $(\mathrm{x})$ and oven-dry weight $(\mathrm{y})$ for each leaf species and each conditioning period

\begin{tabular}{|c|c|c|c|c|c|}
\hline Leaf type and conditioning period & Relationship & $\mathrm{r}^{2}$ & $\mathrm{~F}$ & d.f. & $\mathrm{P}$ \\
\hline \multicolumn{6}{|l|}{ Apodytes brachystylis } \\
\hline 2 weeks & $\mathrm{y}^{1 / 4} 0.130 \mathrm{x}$ p 0.040 & 0.74 & 79.15 & 1,28 & $\mathbf{0} 0.0001$ \\
\hline 4 weeks & $\mathrm{y}^{1 / 4} 0.098 \mathrm{x} 0.028$ & 0.54 & 33.56 & 1,28 & $\mathbf{0} 0.0001$ \\
\hline 10 weeks & $\mathrm{y}^{1 / 4} 0.108 x \mathbf{p} 0.004$ & 0.80 & 118.30 & 1,28 & $\mathbf{0} 0.0001$ \\
\hline \multicolumn{6}{|l|}{ Marattia salicina } \\
\hline 2 weeks & $\mathrm{y}^{1 / 4} 0.140 \mathrm{x} \mathrm{p} 0.015$ & 0.95 & 496.03 & 1,28 & $\mathbf{O} 0.0001$ \\
\hline 4 weeks & $\mathrm{y}^{1 / 4} 0.108 \mathrm{x}$ p 0.017 & 0.94 & 422.18 & 1,29 & $\mathbf{O} 0.0001$ \\
\hline 10 weeks & $\mathrm{y}^{1 / 4} 0.092 \mathrm{x} 0.003$ & 0.92 & 333.60 & 1,28 & $\mathbf{0} 0.0001$ \\
\hline \multicolumn{6}{|l|}{ Cryptocarya leucophylla } \\
\hline 2 weeks & $\mathrm{y}^{1 / 4} 40.307 x-0.004$ & 0.52 & 30.77 & 1,28 & $\mathbf{0} 0.0001$ \\
\hline 4 weeks & $y^{1 / 4} 0.303 x-0.002$ & 0.83 & 133.07 & 1,28 & $\mathbf{0} 0.0001$ \\
\hline 10 weeks & $\mathrm{y}^{1 / 4} 0.303 \mathrm{x}-0.025$ & 0.87 & 186.43 & 1,28 & $\mathbf{O} 0.0001$ \\
\hline \multicolumn{6}{|l|}{ Cryptocaria densiflora } \\
\hline 2 weeks & $\mathrm{y}^{1 / 4} 40.335 \mathrm{x} \mathbf{p} 0.027$ & 0.92 & 316.24 & 1,29 & $\mathbf{O} 0.0001$ \\
\hline 4 weeks & $\mathrm{y}^{1 / 4} 0.340 \mathrm{x} 0.009$ & 0.97 & 956.26 & 1,29 & $\mathbf{0} 0.0001$ \\
\hline 10 weeks & $\mathrm{y}^{1 / 4} 0.355 x-0.004$ & 0.97 & 991.61 & 1,24 & $\mathbf{0} 0.0001$ \\
\hline
\end{tabular}




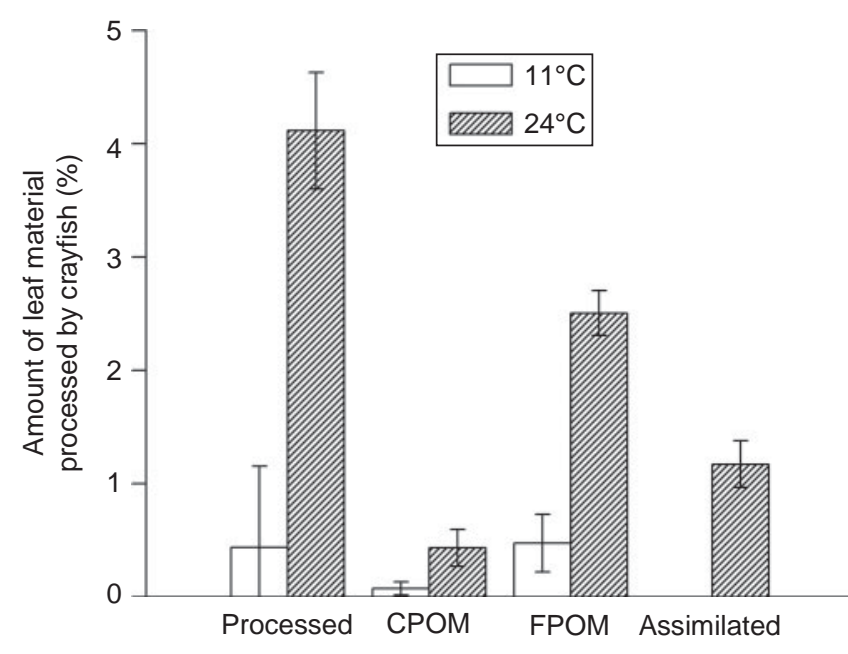

Fig. 3. Amounts of leaf material processed and assimilated and amounts of coarse particulate organic matter (CPOM) and fine particulate organic matter (FPOM) produced (all \%, as per Fig. 2) by crayfish held at $118 \mathrm{C}$ and 248C. $n^{1 / 4} 5$ for treatment and $n^{1 / 4} 3$ for control.

the two Cryptocaria species, contrasting with increasing processing with increased conditioning for A. brachystylis and M. salicina. Individual crayfish differences had no significant effect on processing $\left(F_{1,9} 1 / 41.90, \mathrm{P}^{1 / 4} 40.1183\right)$.

In the second trial, crayfish showed a significant preference for leaves conditioned for 10 weeks over those conditioned for 4 and 2 weeks $(0.02 \mathbf{4} 0.009 \mathbf{4}-0.007$ g processed per gram bodyweight, respectively) $\left(\mathrm{F}_{2,17} 1 / 426.55\right.$, P O 0.0001). There was no significant difference in the amount processed between newly collected crayfish and those that had been acclimated to laboratory conditions for several months ( $\left.F_{1,4} \mathrm{O} 0.1, \mathrm{P} 40.05\right)$.

Experiment 2: effect of temperature on processing rate, production of fine particulate organic matter and assimilation efficiency

Animals at $118 \mathrm{C}$ were less active than animals at $248 \mathrm{C}$, and the resultant effect of temperature on processing was pronounced. Significantly more material was processed at $248 \mathrm{C}$ than at 118C ( $F_{1,4} 1 / 417.41, \mathrm{P}_{1 / 4}$ 0.0031) (Fig. 3). Correspondingly, the amount of FPOM produced was significantly higher at 248C than 118C $\left(\mathrm{F}_{1,4} 1 / 4\right.$ 98.08, P O 0.0001). This FPOM consisted of faecal material and fine fragments resulting from the mechanical action of the mouthparts. The shredding activity of the crayfish also produced significantly more fragmentary CPOM at $248 \mathrm{C}$ than at $118 \mathrm{C}\left(\mathrm{F}_{1,4} 1 / 45.74, \mathrm{P}^{1 / 4} 0.04\right)$. Crayfish in the $118 \mathrm{C}$ treatment assimilated no material over the duration of the experiment. All leaf material processed was converted to fine or fragmentary coarse particulate matter. In contrast, animals at $248 \mathrm{C}$ assimilated up to $28.5 \%$ of the material they processed and converted $71.5 \%$ to fine or fragmentary CPOM.

\section{Leaf properties}

There was a significant difference in leaf toughness among species $\left(\mathrm{F}_{2,4} 1 / 4\right.$ 50.91, P O 0.0001) (Fig. 4). C. densiflora was consistently tougher than all other species whereas A. brachystylis was the least tough of all species at all conditioning

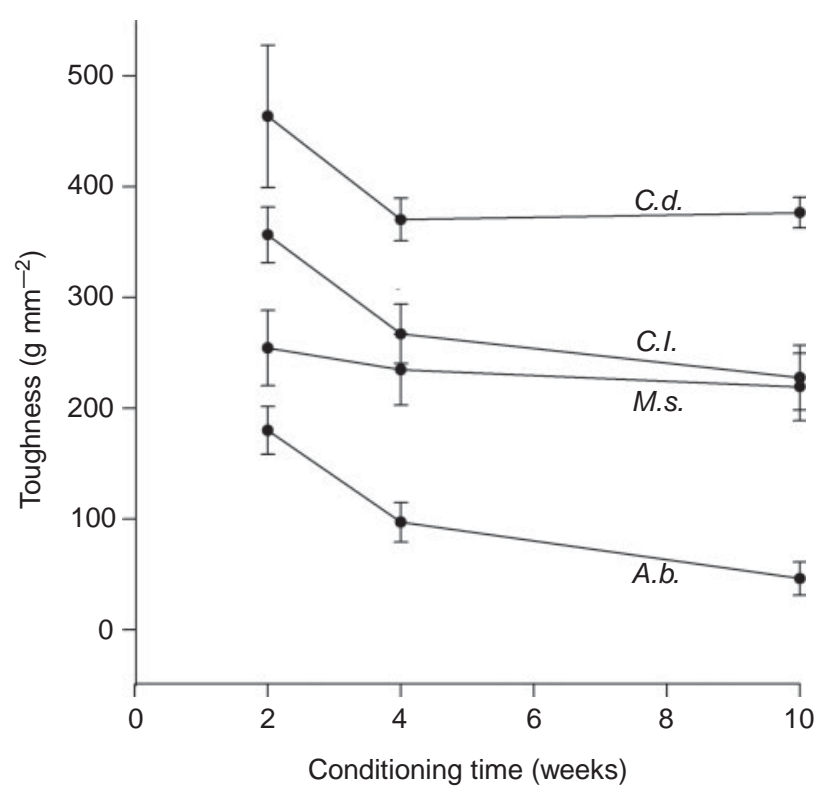

Fig. 4. Mean toughness (mass (g) required to penetrate $1.0 \mathrm{~mm}^{2}$ of leaf tissue, Ts.e.) of each leaf species at each condition (2, 4 and 10 weeks' conditioning period). Species’ abbreviations as in Fig. 2; n1/4 8.

times. Differences in the toughness of leaves among the different conditioning treatments were significant $\left(F_{2,4} 1 / 411.33\right.$, $\mathrm{P} 1 / 40.0001)$. The decline in toughness owing to conditioning from 2 to 4 weeks was more pronounced than that between 4 weeks and 10 weeks. The lack of an interaction effect $\left(F_{2,6} 1 / 40.75, P 1 / 40.6144\right)$ indicates that condition acts independently of species to affect the toughness of the leaf, and that species has an effect on toughness regardless of the condition of the leaf.

Nitrogen content of leaves ranged from 1.45\% (2-weekconditioned C. densiflora) to 2.72\% (10-week-conditioned M. salicina) (Fig. 5). Unconditioned green leaves (time zero) of all species had a higher nitrogen content than leaves conditioned for 2 weeks. After the initial leaching of nitrogen from fresh green leaves, there was an increase corresponding to continued conditioning in the stream. The increase was somewhat delayed in C. leucophylla and C. densiflora, suggesting that microbial colonisation of these species was slower. These two species had very similar nitrogen levels. Differences in nitrogen content among species were significant $\left(F_{1,3} \frac{1}{4} 417.64\right.$, $\mathrm{P} 1 / 40.0022)$, as were differences in variously conditioned leaves ( $\left.F_{1,3} 1 / 46.82, P^{1 / 4} 0.0285\right)$.

Green leaves from different trees within a species showed no variation in nitrogen content: for $\mathrm{A}$. brachystylis, $\mathrm{F}_{1,4} 1 / 4$ 0.67, P 1/4 0.626; for M. salicina, $F_{1,4} 1 / 40.80, \mathrm{P}^{1 / 4} 0.585$; for C. leucophylla, $\mathrm{F}_{1,3} \frac{1 / 4}{4} 0.25, \mathrm{P}^{1 / 4} \mathrm{0.859}$; and for C. densiflora, $\mathrm{F}_{1,4} 1 / 41.64, \mathrm{P}^{1 / 4} \mathrm{0.321}$. There was a significant negative correlation between the amount of each leaf type processed by the crayfish and the toughness of the leaf type $\left(\mathrm{r}^{1 / 4}-0.6296\right.$, P $1 / 40.0282$ ) (cf. Figs 2, 4). A. brachystylis was the least tough and most preferred at all conditions. M. salicina was tougher and processed less than A. brachystylis. The two species of Cryptocarya were toughest overall and were not processed. Nitrogen content of C. densiflora and C. leucophylla did not increase 


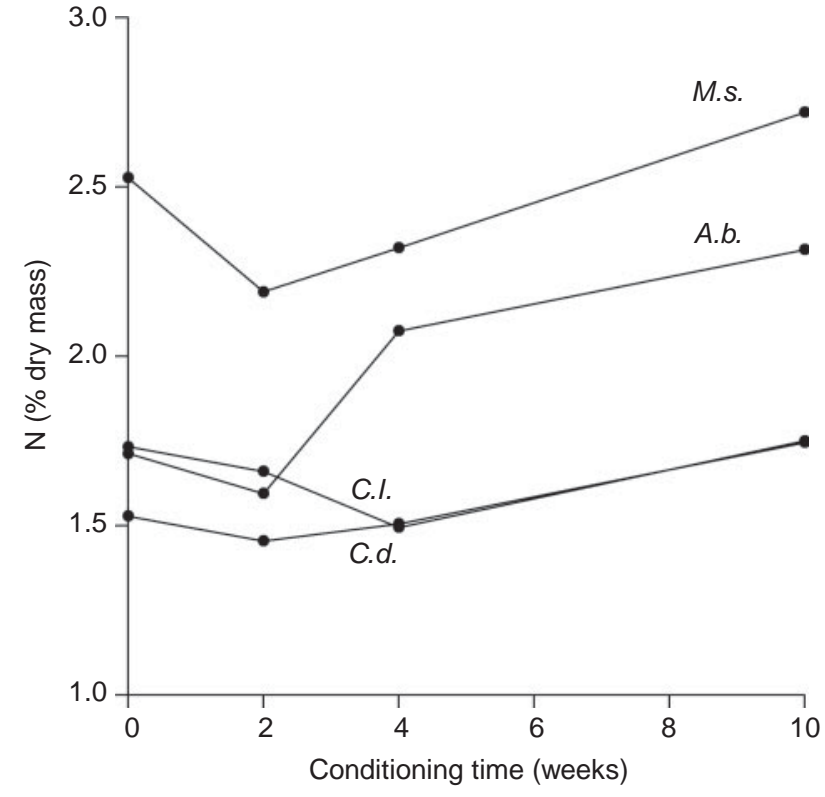

Fig. 5. Nitrogen content (\% dry mass) of each leaf species at each condition (2, 4 and 10 weeks' conditioning period) (based on pooled leaf samples). Species' abbreviations are as in Fig. 2.

between immersion for 2 weeks and that for 4 weeks, unlike it did for A. brachystylis and M. salicina (Fig. 5).

The amount of leaf processed was positively correlated with the nitrogen content of the leaf type ( $\mathrm{r}^{1 / 1} / 40.6607, \mathrm{P}^{1 / 4}$ 0.0193) (cf. Figs 2, 5). A. brachystylis leaves contained less nitrogen than did M. salicina leaves. The nitrogen contents of C. leucophylla and C. densiflora were lower again, although similar to each other. Nitrogen content was shown to decrease initially from fresh leaves and increase again after conditioning (Fig. 5). In an unweighted least-squares linear regression, nitrogen content and toughness explained $53 \%$ of the observed variation in the amount of each leaf type processed $\left(F_{1,9} 1 / 45.066, P 1 / 40.03\right)$. The equation that describes the relationship between nitrogen content $(\% \mathrm{~N})$, toughness (g per $3 \mathrm{~mm}^{2}$ ) and processing (g per gram bodyweight) is as follows:

$$
\text { Amount processed } \begin{aligned}
1 / 4 & -0: 73 \mathrm{p} \text { ð0:96 } \times \% \mathrm{~Np} \\
& -ð 9: 23 \times 10^{-5} \times \text { toughnessp: }
\end{aligned}
$$

\section{Discussion}

\section{Litter dynamics}

Retention of litter in streams provides the critical link between input and storage, which allows utilisation of this energy source by the stream community (Speaker et al. 1984). Litter fall at Birthday Creek reached a peak in the late dry season (spring/ early summer) and accumulation in the stream was similar to the long-term trend over 3 years (Benson and Pearson 1993) and to accumulation in Yuccabine Creek, another Queensland rainforest stream (Pearson et al. 1989). Wet-season spates affected litter accumulation, with cyclonic floods flushing all litter from the stream, as normally occurs (Pearson 2005).
Cyclonic activity defoliates trees and initiates a period of leaf flush (newly expanded leaves) (Hopkins and Graham 1987). This period is immediately followed by several months of minimal litter fall (Fig. 3) in which a large proportion of the leaf fall is likely to be fresh. Standing crop was not measured after March; however, other observations have shown that litter gradually builds up in both riffles and pools (Pearson 2005). During this period, the standing crop in riffles may exceed that in pools for a short period, because green leaf litter does not sink in the pools but instead is trapped at the head of riffles.

\section{Processing by crayfish}

The results of Experiment 1 indicated a clear preference of C. cairnsensis for well-conditioned leaves; however, regardless of condition, A. brachystylis was preferred over other species. Two effects of conditioning which may act independently to influence the choice are the increase in nitrogen content and the reduction in leaf toughness. Nitrogen is a vital nutrient for animal metabolism and is often a limiting factor (Mattson 1980). Toughness can be regarded as an indicator of the tendency for a leaf to be shredded, and results from a combination of leaf characters such as cuticle thickness, presence of wax, degree of sclerotisation, moisture content and venation density. Coley (1983) found that over $70 \%$ of the variation in rates of herbivory could be explained by leaf properties such as pubescence, toughness, water content, protein, fibre and phenolic contents. Of these, toughness was the factor most highly correlated with leaf herbivory.

The results of the present study suggest that, regardless of the nutrient quality of the leaf, there are morphological and behavioural restrictions to processing by crayfish. Thus, the crayfish may be incapable of physically breaking down the tough leaf material, given the morphology of their mouthparts, or a lack of suitable enzymes for digestion may inhibit the utilisation of the leaf material. However, although the inability to break down structural polysaccharides has been reported as widespread among freshwater crayfish (Musgrove 1988), more recent literature has suggested that Cherax species have appropriate cellulose and hemicelluslase enzymes (e.g. Byrne et al. 1999; Davison and Blaxter 2005) and are believed to be capable of substantial cellulose and hemicellulose digestion, without the need for symbiotic microorganisms (Jones and DeSilva 1997; Byrne et al. 1999). In the present study, leaf material was not processed when microbial conditioning had not occurred, as evidenced by the lack of increase in nitrogen content after 4 weeks of immersion in stream water. This may simply reflect the preference for more nutrient-rich conditioned leaves rather than an inability to digest leaf material.

An alternative explanation for the leaf preferences is the existence of a factor such as a high level of condensed tannins, which may override the apparent palatability in terms of nitrogen content. Ferns have relatively high levels of such defensive compounds compared with higher vascular plants (B. Jackes, James Cook University, pers. comm.), which may explain why A. brachystylis was preferred over the fern M. salicina, despite the higher nitrogen content of the latter species.

In general, assimilation efficiencies for detritus are low, with means ranging from 6 to 35\% (Berrie 1976). Musgrove (1988) found that P. zealandicus had an assimilation efficiency of 
12-28\% when fed on Elodea leaves. C. cairnsensis assimilated up to $28 \%$ of the processed leaf material at $248 \mathrm{C}$, whereas it assimilated none at $118 \mathrm{C}$. This result, and the finding that only very small amounts of leaf material were processed at $118 \mathrm{C}$, suggests that the contribution of C. cairnsensis to litter processing in winter will be negligible, although stream temperature does not normally remain as low as $118 \mathrm{C}$ for extended periods (R. G. Pearson, unpubl. data). However, the contribution of C. cairnsensis to litter breakdown in the summer can be important. The population density of C. cairnsensis in Birthday Creek was estimated to be , 0.5 animals per $\mathrm{m}^{2}$, using mark-recapture and random benthic sampling techniques (J. F. Coughlan, unpubl. data). Given the breakdown rates determined in the present study, it is estimated that , $1 \%$ of the detritus entering Birthday Creek is processed by the crayfish. Although this might suggest that food is not limiting for this species, except following floods, it is not known how much of the litter fall is useful (i.e. palatable and nutritious); for example, of the common litter species tested here, the Cryptocaria species are apparently unavailable to the crayfish.

\section{Trophic dynamics}

These results raise interesting questions about the trophic basis of production for $\mathrm{C}$. cairnsensis. Processing rates should be highest in summer (Experiment 2), which is the time when peak litter fall occurs. However, cyclonic and/or monsoonal activity, which is characteristic of the summer months in the tropics, results in heavy rains that flush much of the litter from the stream, as occurred after Cyclone Ivor. Thus, litter that has fallen in October and November will have been subjected to about 4 months of stream conditioning before being washed out. For some species, this may be ample time for leaves to be suitably conditioned, whereas species that appear resistant to microbial colonisation may require longer (e.g. members of the genus Cryptocarya). For this reason, the flush of green litter fall, which is a feature associated with cyclones (Hopkins and Graham 1987), may be of particular dietary importance to stream shredders during the absence of optimally conditioned litter. However, C. cairnsensis did not process fresh leaves, in contrast to the caddisfly larva Anisocentropus kirramus, which processes, and in some cases actually prefers, fresh green leaves (Nolen and Pearson 1993). The inability of the crayfish to process fresh leaves may be due to their mouthpart morphology or to the presence of high levels of defensive compounds that occur in fresh rainforest tree leaves (Janzen 1974). Thus, in postcyclone periods, the contribution of alternative food supplies, such as animals, or endogenous reserves, may be important for the crayfish.

\section{Conclusion ] a diversity of shredders}

Our results confirmed that litter processing in tropical streams is not the sole preserve of the shredders expected from temperate systems (such as caddisflies, stoneflies and amphipods). In Australian tropical streams, litter decomposition is effected by microbes (Pearson and Connolly 2000), insects (e.g. Nolen and Pearson 1993; Cheshire et al. 2005) and crayfish. Additionally, recent work has suggested that tadpoles have some role in leaf shredding, especially in combination with insects (Iwai et al. 2009), and that a range of invertebrates such as cockroaches and snails can be involved in this process (Yule et al. 2009). It is important that research on litter decomposition identifies the species involved in processing to quantify breakdown rates properly (Jonsson and Malmqvist 2003a) to identify facilitation and interference effects (Jonsson and Malmqvist 2003b; Bastian et al. 2008; Iwai et al. 2009), and to ensure inclusion of all components of the process. Given the relative sizes of insect and crustacean shredders, and the omnivorous nature of crayfish (Growns and Richardson 1988), it is likely that crayfish interfere not only with insect shredding competitively, but also as predators.

\section{Acknowledgements}

This research was supported by an Australian Research Council grant and by funding from the Cooperative Research Centre for Tropical Rainforest Ecology and Management to R.G.P. Dr Chris Austin kindly confirmed the identification of the crayfish. A permit to work in Birthday Creek was issued by the Queensland National Parks and Wildlife Service. We thank anonymous reviewers and the editor for very helpful comments on the manuscript.

\section{References}

Bastian, M., Boyero, L., Jackes, B. R., and Pearson, R. G. (2007). Leaf preferences by shredders in tropical streams. Journal of Tropical Ecology 23, 219-229. doi:10.1017/S0266467406003920

Bastian, M., Pearson, R. G., and Boyero, L. (2008). Effects of diversity loss on ecosystem function across trophic levels and ecosystems: a test in a detritus-based tropical food web. Austral Ecology 33, 301-306. doi:10.1111/J.1442-9993.2007.01817.X

Benfield, E. F., and Webster, J. R. (1985). Shredder abundance and leaf breakdown in an Appalachian mountain stream. Freshwater Biology 15, 113-120. doi:10.1111/J.1365-2427.1985.TB00701.X

Benson, L. J., and Pearson, R. G. (1993). Litter inputs to a tropical Australian rainforest stream. Australian Journal of Ecology 18, 377-383. doi:10.1111/J.1442-9993.1993.TB00465.X

Berrie, A. D. (1976). Detritus micro-organisms and animals in fresh water. In 'The Role of Terrestrial and Aquatic Organisms in Decomposition Processes'. (Eds J. M. Anderson and A. MacFadyen.) pp. 323-338. (Blackwell Scientific Publications: Melbourne.)

Bird, G. A., and Kaushik, N. K. (1985). Processing of elm and maple leaf discs by collectors and shredders in laboratory feeding studies. Hydrobiologia 126, 109-120. doi:10.1007/BF00008677

Boyero, L., Pearson, R. G., and Camacho, R. (2006). Leaf breakdown in tropical streams: the role of different species in ecosystem functioning. Archiv fuer Hydrobiologie 166, 453-466. doi:10.1127/0003-9136/2006/ 0166-0453

Bremmen, J. M., and Mulvaney, C. S. (1982). Nitrogen - total. In 'Methods of Soil Analysis. Part 2’. (Eds A. L. Page, R. H. Miller and D. R. Keeney.) pp. 595-624. (Soil Science Society of America: Madison, WI.)

Byrne, K. A., Lehnert, S. A., Johnson, S. E., and Moore, S. S. (1999). Isolation of a cDNA encoding a putative cellulase in the red claw crayfish Cherax quadricarinatus. Gene 239, 317-324. doi:10.1016/ S0378-1119(99)00396-0

Cheshire, K., Boyero, L., and Pearson, R. G. (2005). Food webs in tropical Australian streams: shredders are not scarce. Freshwater Biology 50, 748-769. doi:10.1111/J.1365-2427.2005.01355.X

Coley, P. D. (1983). Herbivory and defensive characteristics of tree species in a lowland tropical forest. Ecological Monographs 53, 209-229. doi:10.2307/1942495

Cummins, K. W., Wilzbach, M. A., Gates, D. M., Perry, J. B., and Taliaferro, W. B. (1989). Shredders and riparian vegetation. BioScience 39, 24-30. doi:10.2307/1310804 
Davison, A., and Blaxter, M. (2005). Ancient origin of glycosyl hydrolase family 9 cellulase genes. Molecular Biology and Evolution 22, 1273-1284. doi:10.1093/MOLBEV/MSI107

Dobson, M. (2004). Freshwater crabs in Africa. Freshwater Forum 21, 3-26.

Graça, M. A. S., and Zimmer, M. (2005). Leaf toughness. In 'Methods to Study Leaf Decomposition’. (Eds M. A. S. Graca, F. Barlocher and M. O. Gessner.) pp. 121-128. (Springer: Dordrecht, The Netherlands.)

Growns, I. O., and Richardson, A. M. M. (1988). Diet and burrowing habits of the freshwater crayfish Parastacoides tasmanicus tasmanicus Clark Decapoda: Parastacidae. Australian Journal of Marine and Freshwater Research 39, 525-534. doi:10.1071/MF9880525

Hopkins, M. S., and Graham, A. W. (1987). Gregarious flowering in a lowland tropical rainforest: a possible response to disturbance by Cyclone Winifred. Australian Journal of Ecology 12, 25-29. doi:10.1111/J.14429993.1987.TB00924.X

Iwai, N., Pearson, R. G., and Alford, R. A. (2009). Shredder-tadpole facilitation of leaf litter decomposition in a tropical stream. Freshwater Biology 54, 2573-2580. doi:10.1111/J.1365-2427.2009.02267.X

Janzen, D. H. (1974). Tropical blackwater rivers, animals, and mast fruiting by Dipterocarpaceae. Biotropica 6, 69-103. doi:10.2307/2989823

Jones, P. L., and De Silva, S. S. (1997). Apparent nutrient digestibility of formulated diets by the Australian freshwater crayfish Cherax destructor Clark (Decapoda, Parastacidae). Aquaculture and Research 28, 881-891. doi:10.1111/J.1365-2109.1997.TB01012.X

Jonsson, M., and Malmqvist, B. (2003a). Importance of species identity and number for process rates within different stream invertebrate functional feeding groups. Journal of Animal Ecology 72, 453-459. doi:10.1046/ J.1365-2656.2003.00714.X

Jonsson, M., and Malmqvist, B. (2003b). Mechanisms behind positive diversity effects on ecosystem functioning: testing the facilitation and interference hypotheses. Oecologia 134, 554-559.

Lau, C. P., Keung, K. M. Y., and Dudgeon, D. (2008). Experimental dietary manipulations for determining the relative importance of allochthonous and autochthonous food resources in tropical streams. Freshwater Biology 53, 139-147.

Lau, C. P., Keung, K. M. Y., and Dudgeon, D. (2009). What does stable isotope analysis reveal about trophic relationships and the relative importance of allochthonous and autochthonous resources in tropical streams? A synthetic study from Hong Kong. Freshwater Biology 54, 127-141. doi:10.1111/J.1365-2427.2008.02099.X

Lorman, J. G., and Magnuson, J. J. (1978). The role of crayfishes in aquatic ecosystems. Fisheries 3, 8-10.

Mattson, W. J., Jr (1980). Herbivory in relation to plant nitrogen content. Annual Review of Ecology and Systematics 11, 119-161. doi:10.1146/ ANNUREV.ES.11.110180.001003
Musgrove, R. J. (1988). Digestive ability of the freshwater crayfish Paranephrops zealandicus (White) (Parastacidae) and the role of microbial enzymes. Freshwater Biology 20, 305-314. doi:10.1111/J.1365-2427. 1988.TB00456.X

Nolen, J. A., and Pearson, R. G. (1992). Life history studies of Anisocentropus kirramus Neboiss (Trichoptera: Calamoceratidae) in a tropical Australian rainforest stream. Aquatic Insects 14, 213-221. doi:10.1080/ 01650429209361487

Nolen, J. A., and Pearson, R. G. (1993). Factors affecting litter processing by Anisocentropus kirramus Trichoptera: Calamoceratidae from an Australian tropical rainforest stream. Freshwater Biology 29, 469-479. doi:10.1111/J.1365-2427.1993.TB00781.X

Pearson, R. G. (2005). Biodiversity of the freshwater fauna of the Wet Tropics region of north-eastern Australia: patterns and possible determinants. In 'Tropical Rain Forests: Past, Present and Future'. (Eds E. Bermingham, C. W. Dick and C. Moritz.) pp. 470-485. (University of Chicago Press: Chicago, IL.)

Pearson, R. G., and Connolly, N. M. (2000). Nutrient enhancement, food quality and community dynamics in a tropical rainforest stream. Freshwater Biology 43, 31-42. doi:10.1046/J.1365-2427.2000.00504.X

Pearson, R. G., and Tobin, R. K. (1989). Litter consumption by invertebrates from an Australian tropical rainforest stream. Archiv für Hydrobiologie 116, 71-80.

Pearson, R. G., Tobin, R. K., Smith, R. E. W., and Benson, L. J. (1989). Standing crop and processing of rainforest litter in a tropical Australian stream. Archiv für Hydrobiologie 115, 481-498.

Rosemond, A. D., Pringle, C. M., and Ramirez, A. (1998). Macroconsumer effects on insect detritivores and detritus processing in a tropical stream. Freshwater Biology 39, 515-523. doi:10.1046/J.1365-2427.1998.00301.X Snedecor, G. W., and Cochran, W. G. (1980). 'Statistical Methods.' 7th edn. (Iowa State University Press: Ames, IA)

Speaker, R., Moore, K., and Gregory, S. (1984). Analysis of the process of retention of organic matter in stream ecosystems. Verhandlungen der Internationalen Vereinigung für Theoretische und Angewandte Limnologie 22, 1835-1841.

Usio, N. (2000). Effects of crayfish on leaf processing and invertebrate colonisation of leaves in a headwater stream: decoupling of a trophic cascade. Oecologia 124, 608-614. doi:10.1007/S004420000422

Yule, C. M., Leong, M. Y., Ratnarajah, L., Schmidt, K., Wong, H. M., Pearson, R. G., and Boyero, L. (2009). Shredders in Malaysia: abundance and richness are greater in cool highland tropical streams. Journal of the North American Benthological Society 28, 404-415. doi:10.1899/07-161.1

Manuscript received 3 June 2009, accepted 18 October 2009 